УДК 069.015

DOI: $10.33099 / 2707-1383-2020-38-4-78-91$

Чечин О.А., викладач,

Військовий коледж сержантського складу

Харківського національного університету

Повітряних Сил України імені Івана Кожедуба

(м. Харків, Україна)

«Видатні університети мають видатні музеї»

Пітер Б. Тірелл

\title{
ІСТОРІЯ МУЗЕЮ ХАРКІВСЬКОГО НАЦІОНАЛЬНОГО УНІВЕРСИТЕТУ ПОВІТРЯНИХ СИЛ УКРАЇНИ ІМЕНІ ІВАНА КОЖЕДУБА
}

У статті розглянуто історію музею Харківського національного університету Повітряних Сил імені Івана Кожедуба. Висвітлюється концепція музею, іі витоки та форми реалізації. Окрема увага приділена інноваційним ріменням і використанню сучасних інформаційних технологій у музейній справі. Окреслені перспективи розвитку музею. Запропонована модель єдиного інформаиійного простору для військових музеїв.

Ключові слова: історія, музей, аналіз, концепція, інновації, мультимедіа, інтерактивність, QR-код, контент, система.

Історія музею Харківського університету Повітряних Сил імені Івана Кожедуба тісно пов'язана з історіями музеїв військових навчальних закладів Харківщини, починається вона 3 одного зі старіших закладів - музею Харківської військової інженерної радіотехнічної академії ППО ім. Л. О. Говорова.

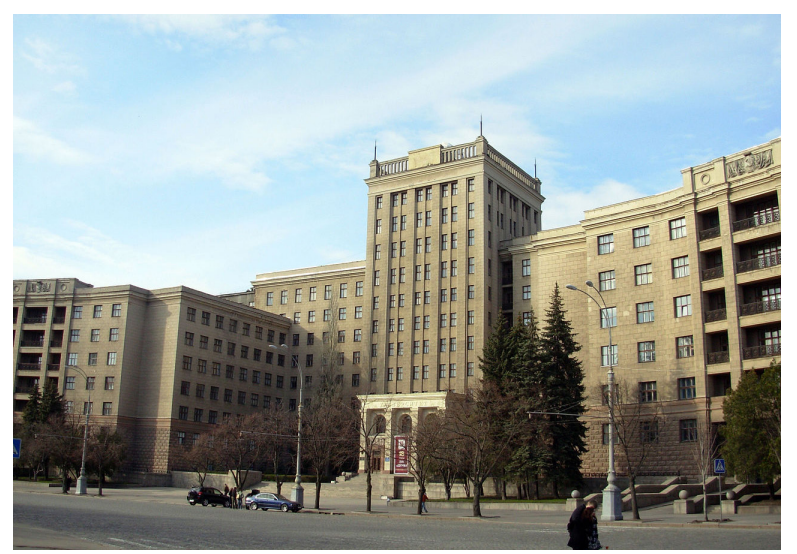

Будівля академії ППО ім. Говорова на площі Свободи
Музей академії було засновано в середині 50-х років минулого століття. Він знаходився на четвертому поверсі центрального корпусу будівлі, розташованої на площі Свободи. Експозиція займала 9 залів, загальною площею 600 кв. м.

Наповнення музею було досить типовим для своїх часів, на стендах відображалася історія академії, її сьогодення, досягнення випускників і знаходилися макети озброєння. В процесі розвитку до колекції додавалися особисті речі, того ж Л.О. Говорова, прапори військових частин, в тому числі і з'єднань, які у 1943 році звільняли Харків від нацистських загарбників і отримали назву «Харківські». Музеєм завідував великий ентузіаст своєї справи прапорщик запасу О.А. Глушко.

У 1996 році академія об'єдналася з Харківським вищим військовим командно-ін- 
женерним училищем ракетних військ ім. М. І. Крилова в єдиний навчальний заклад - Харківський військовий університет.

Музей ХВВКІУ ім. М. І. Крилова відкрився 1977 року, він розміщався в клубі училища на п'ятому та шостому поверхах. Експозиція містила багато цікавих експонатів, пов'язаних з історією ракетного озброєння та ракетних військ СРСР. Серед них слід особливо відзначити особисті речі маршала М.І. Крилова, велику кількість макетів ракет, пускових комплексів, цікаві фото і документи.

Керівництво нового університету розташувалося в будівлі академії, тому іiі музей став базовим для обох закладів, а його експозицію доповнили за рахунок експонатів училища імені М.I. Крилова. 2003 року на базі Харківського військового університету і Харківського інституту Військово-Повітряних Сил було створено новий військовий навчальний заклад - Харківський університет Повітряних Сил. В історії музею почалася нова сторінка пов'язана $з$ авіацією. Але переформатуватися під нові реалії музей не встиг.

2004 року Збройні Сили безкоштовно передали величезну будівлю ХВУ Харківському національному університету імені В.Н. Каразіна. Керівництво університету переїхало на нову базу - в корпуси училища ім. М.І. Крилова, які знаходилися на вулиці Сумській в центрі міста Харкова. Однак музей не міг покинути свої приміщення, бо ні нового місця дислокації, ні коштів на переїзд йому не виділялося. Деякий час музей функціонував на старій базі. В 2005 році, після присвоєння університету імені Івана Кожедуба, в музеї було створено відповідну виставку.

В 2008 році керівництво ХНУ імені В.Н. Каразіна «віддячило» військовим за подарунок будівлі, і вирішило виселити «чужий» музей. Після судової тяганини до музею завітала виконавча служба і приміщення були вилучені. Експозицію довелося згорнути та перемістити в клуб університету. Почалася робота 3 відновлення музею на новому місці.

Розбудову оновленого музею прискорило 80-річча Харківського вищого військового авіаційного училища льотчиків ім. С. І. Грицевця. Університет, як провідний заклад підготовки українських льотчиків фактично був правонаступником училища льотчиків, а випускниками цього відомого навчального закладу були сотні Героїв Радянського Союзу і десятки космонавтів. Тому свято вирішили зробити масштабним, майже державного рівня. На нього з'їзжалися чисельні закордонні гості.

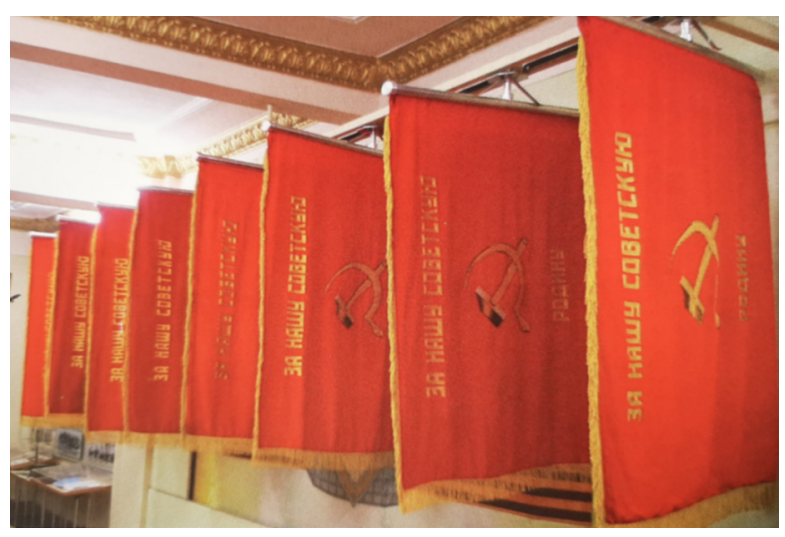

Прапори військових частин в музеї академії ППО ім. Говорова

До цієї події музей було майже закінчено. Нарешті в одному місці була сформована єдина експозиція, яка охоплювала 80 років історії Харківського університету Повітряних Сил імені Івана Кожедуба, з 1930 року (рік заснування Чугуївської школи пілотів) по 2010 рік.

Експозиція складалася зі стендів та колекцій музеїв Харківської військової інженерної радіотехнічної академії ППО ім. Л. О. Говорова, Харківського вищого військового командно-інженерного училища 


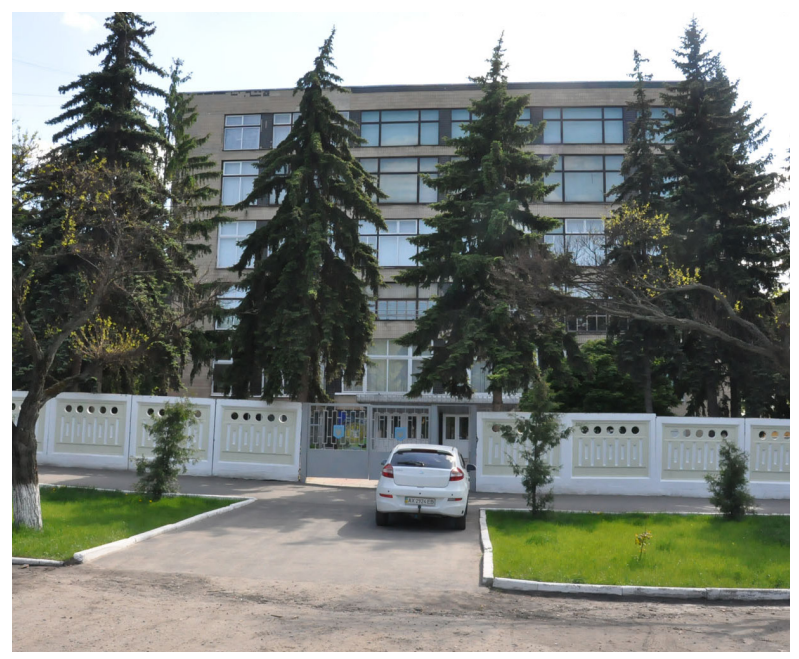

Будівля клубу університету.

Музей займає 5 та 6 поверхи

ракетних військ ім. М.І. Крилова, Харківського вищого військового авіаційного училища льотчиків ім. С.І. Грицевця. В основі лежали особисті речі, книги та відзнаки видатних особистостей радянського періоду, життя яких було пов'язане з цими навчальними закладами. Зокрема: Маршалів Л.О. Говорова, Ю.П. Бажанова, заслужених діячів науки і техніки Радянської України професорів Я.Д. Ширмана (винахідник квадратурного автокомпенсатора першкод), Я.С. Шифріна (засновник статистичної теорії антен). Також слід відзначити частини конструкції літака U-2 Френсіса Г. Пауерca, які були передані в академію ППО Центральним музеєм Збройних сил СРСР.

3 музею ХВВАУЛ в колекцію додалися особисті речі радянських космонавтів, які в різні часи випускалися 3 училища льотчиків, сувеніри та подарунки, окремі документи та фото. Слід відмітити особисті речі та форму Івана Кожедуба, фото і документи пов'язані з життям видатного льотчика радянського періоду Сергія Гріцевця. Велику роботу по зберіганню цих матеріалів вів завідувач музею ХВВАУЛ полковник запасу Л.В. Бобейко.

12 листопада 2010 року музей історії Харківського університету Повітряних Сил

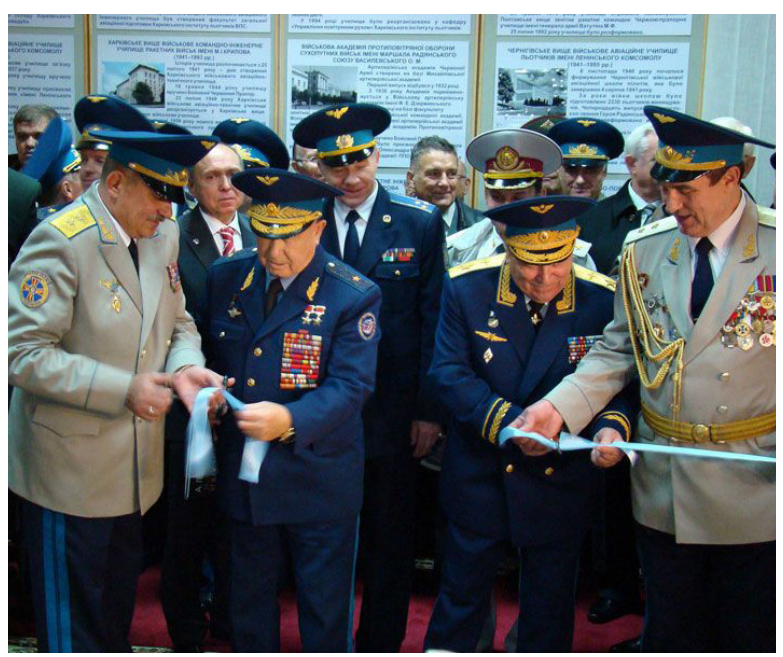

Церемонія відкриття музею 12.11.2010. Начальник університету генерал-лейтенант В.І. Ткаченко з випускниками різних років

було урочисто відкрито. Також у дворі університету відкрили пам'ятник Івану Кожедубу.

Після 2010 року робота над подальшим розвитком експозиції не припинялася. В колекцію додавалися окремі експонати, пов'язані з відвіданням університету різноманітними делегаціями, святкуваннями визначних дат і ювілеїв. Оновлювалася інформація на стендах, які відображали зміни в керівництві Збройних сил України.

В листопаді 2013 року за підтримки начальника Харківського університету Повітряних Сил ім. І. Кожедуба генерал-майора А.М. Алімпієва та Харківського міського голови Г.А. Кернеса, на першому поверсі клубу університету розпочалося створення громадського музею «Обереги музичної Харківщини». В основу музею лягла особиста колекція секретаря Харківської організації Спілки композиторів, службовця ЗС України Ю.Л. Щербініна. Експозиція розповідала про розвиток музичної культури Харкова за період з кінця 18-го століття по сьогоднішній день. Музей відкрився для відвідувачів у серпні 2014 року. Враховуючи його вдале розташування (перший поверх) і сучасний ди- 
зайн інтер'єру він часто використовується для відвідань, як візитівка університету, бо на п'ятий поверх підніматися досить важко. В приміщенні цього музею проводяться різноманітні культурні заходи та заняття з курсантами [1].

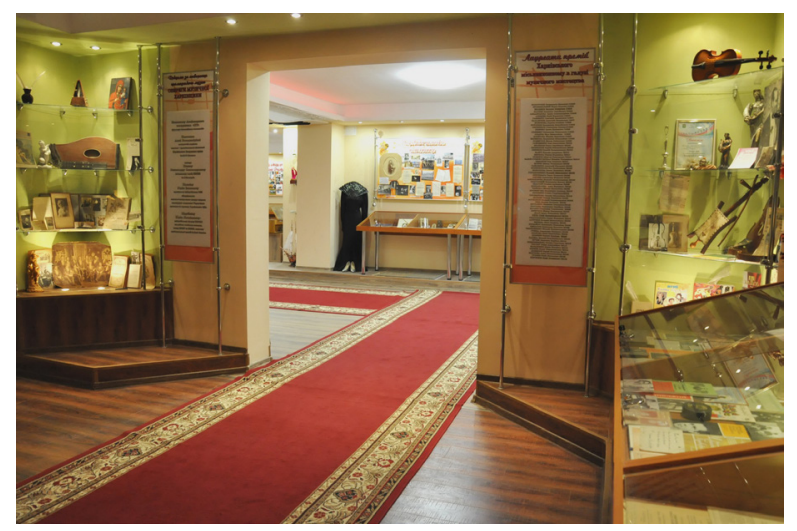

Інтер'єр громадського музею «Обереги музичної Харківщини»

Після початку Російської збройної агресії проти України, в музеї на шостому поверсі було облаштовано відповідний розділ, створені стенди присвячені Антитерористичній операції та героїчним вчинкам наших воїнів.

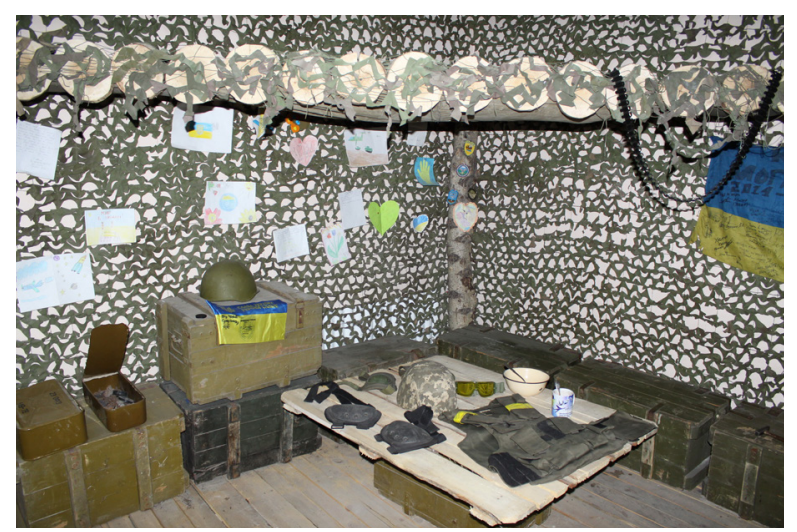

Фрагмент експозиції присвяченої АТО

В 2017 році естафету керування музеєм прийняв полковник запасу О.Г. Шаповал.

В кінці 2018 року в ХНУПС було вирішено змінити застарілу концепцію музею.

\section{Концепція Музею}

Розробці нової концепції передував аналіз ситуації в якій опинився музей ХНУПС станом на 2018 рік. Також розглядалися загальні воєнно-історичні питання, які пов'язані з історією авіації, ракетної техніки, техніки радіолокації і зв'язку в Україні. Був проведений пошук джерел інформації, а також розглянута потенція різних воєнно-історичних інституцій.

Аналіз експозиції музею зразка 2010 року показав, що він фактично продовжує лінію музеїв радянських навчальних закладів, які виховували офіцерів у дусі відданості «партії та радянському народу». Ідеологія музею повністю вкладалася у російську парадигму, яка базується на твердженні, що українська армія немає своєї історії, що вона є частиною радянської та випадково відокремилася від неї. Події Перших визвольних змагань, історія українських збройних формувань різних періодів, життя видатних українців, які не пов'язані з Червоною армією, в музеї представлені не були.

Більшість інформаційних стендів робилися звичайним перекомпонуванням матеріалів радянського періоду, що легко побачити на знімку.
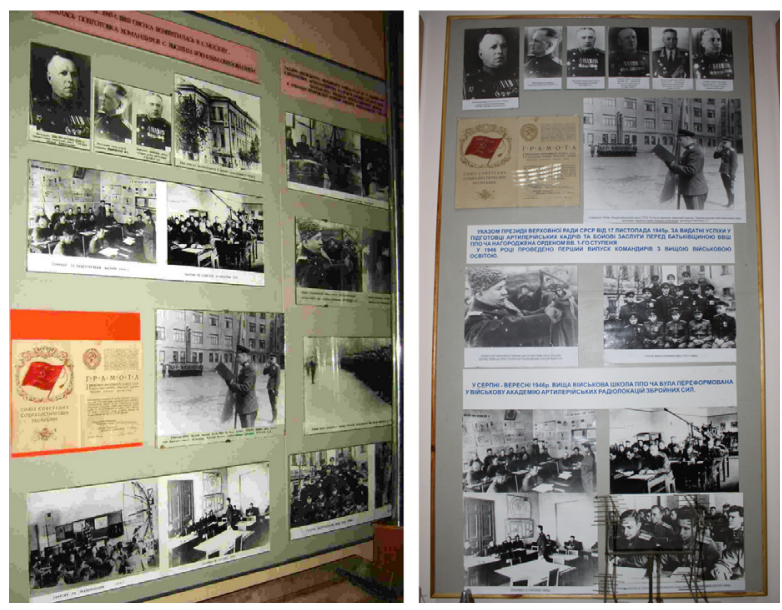

Ліворуч стенд з музею ХВУ, праворуч - з музею ХУПС 2010 року 
Деякі стенди висвітлювали інформацію про героїчні вчинки військовослужбовців радянського періоду. Наприклад, подія 1980 року, коли курсант врятував дівчину від хуліганів у московському метро. Поруч 3 описом лежала його форма та облікова картка ВЛКСМ. Стенди присвячені історії ХВВАУЛ містили інформацію про комуністичних злочинців 30-х років, причетних до масових репресій і вчинення Голодомору українського народу.

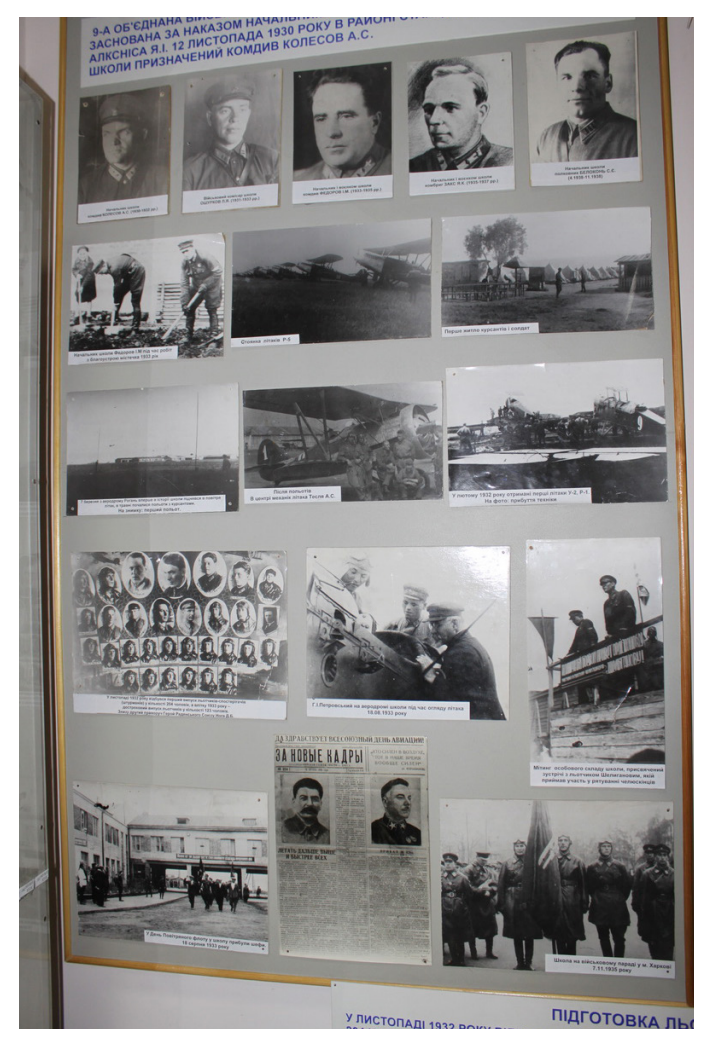

Стенд з музею ХНУПС 2010 року

Відоме прислів'я про те, що «один переїзд дорівнює двом пожежам» майже буквально відобразилося на музейних фондах. Дуже шкода, що частина матеріалів була втрачена в процесі безкінечних реорганізацій і перебазувань, в яких перебували підрозділи університету на початку 2000-х років.

Вище означений ювілей ХВВАУЛ також наніс непоправних втрат. Під приводом підготовки двотомного ювілейного видання (рос.) «Жизнь в авиации и человеческие судьбы», були вивезені до Москви найбільш цінні фотоархіви 3 повсякденного життя ХВВАУЛ, залишилися тільки фото спортивних змагань та партійних зібрань.

Окремо хочеться сказати про технічну складову різних військових училищ Харкова. Перед навчальним корпусом ХВВАУЛ знаходилася виставка бойових літаків, кожен 3 яких мав свою історію. Наприклад, МіГ-21Ф з ЛВІ ім. Н.Н. Громова — на якому літали льотчики випробувачі, в тому числі і Амет-Хан Султан. Замість збереження цієї техніки на території університету іiі передали в музей при Луганському AР3. В різні установи передали і багато іншої авіатехніки, яка могла би скласти унікальну колекцію 3 колосальним виховним i навчальним потенціалом. Серед неї слід виділити МіГ-15УТІ, L-29, ранні модифікації Мi-24А, рідкісний зразок Су-24, МіГ$29 \mathrm{M}$ та багато інших. Частина авіатехніки була просто розукомплектована і порізана на металобрухт. Серед втрачених зразків слід виділити унікальний гелікоптер-тральщик Мі-6, літаючі командні пункти Мі-9, Mi-22, Mi-27.

В свій час університет позбувся також зразків зенітних гармат та іншого озброєння, частина була здана в арсенали, а частина передана в інші установи.

Ще однією важкою втратою для потенційних музейних фондів університету стала передача розрізних макетів ракет 15A18 (Р-36М2) та 8К63 (Р-12), величезної кількості обладнання, наочних посібників і технічної літератури в музей РВСН (селище Побузьке).

Що стосується музею РВСН, то викликає подив те, що зараз туди звозять не тільки озброєння, яке відноситься до його безпосередньої тематики, а ще й і літаки, авіаційні ракети, бомби, зенітні ракети, гармати, бронетехніку та ін. Передані експонати зберігаються в музеї просто неба, 
піддаючись корозії. Територія закладу скоріш нагадує звалище військової техніки. Також його відвідання ускладнене віддаленим розташуванням.

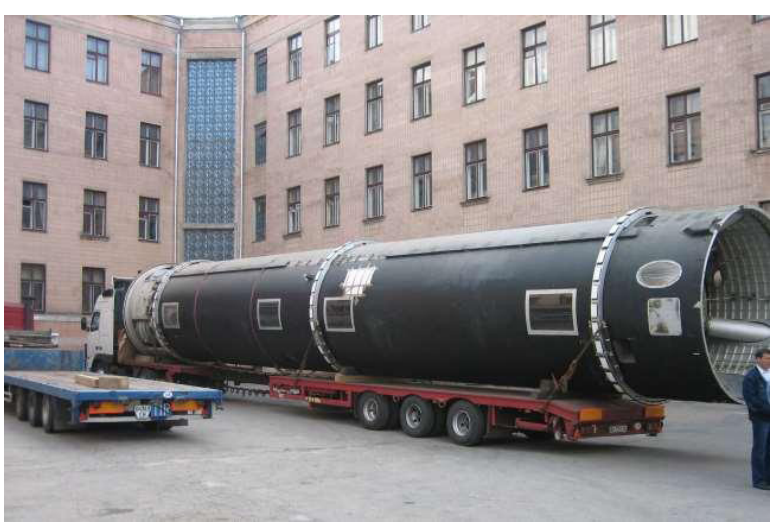

Перша та друга ступені ракети 15A18 завантажені на трейлер

Одне діло, коли повз зразок техніки кожен день проходять курсанти (студенти, школярі) і зовсім інше, коли він іржавіє посеред степу у 20 км від найближчого великого населеного пункту. Складається враження, що єдина концепція розвитку військових музеїв в Україні відсутня.

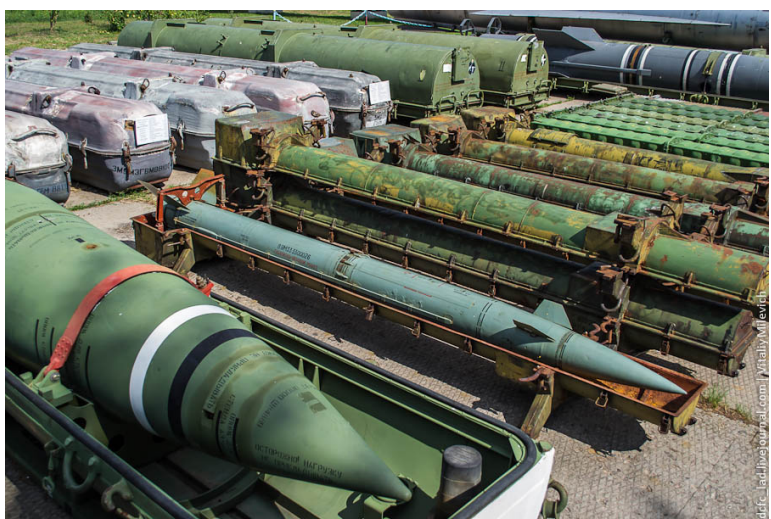

Зенітні ракети комплексу «Оса» на території музею РВСН

Музей втратив багато цікавих потенційних експонатів, які могли б підняти не тільки рівень самого музею, а й університету взагалі. Всі ці втрати стали наслідком байдужості керівництва, відсутності чіткого розуміння ролі історії та зразків озброєння у вихованні майбутніх офіцерів.
Саме ця техніка могла би залучити величезну кількість відвідувачів і сприяти підняттю престижу військової професії. Бо не $\epsilon$ секретом, що кількість бажаючих вступити до військових навчальних закладів падає 3 кожним роком. Молодь практично не цікавиться військовою історією, україномовні популярні видання з історії авіації і ракетної техніки в державі відсутні, а зразки техніки концентруються у важкодоступних місцях.

Оцінюючи ситуацію яка склалася 3 виданнями воєнно-історичної тематики в Україні, слід відзначити, що спеціалізовані наукові видання в Україні існують, їх детальний аналіз станом на 2019 рік зроблено О.О. Пашковою [2], але вони аж ніяк не можуть вважатися популярними, як в сенсі доступності, дизайну так і в стилі викладання матеріалу. Ця інформаційна ніша вщент заповнена російськомовними журналами це: «Популярная механика» (Російська Федерація), «Авиация и время» (Київ), «Наука и техника» (Харків). Звертає на себе особливу увагу останнє видання, яке явно симпатизує російському світу, а у його редакційній колегії фігурує Борис Гризлов. Теж саме можна сміливо екстраполювати і на Інтернет, де ведучу роль джерел інформації відіграють такі ресурси, як: airwar.ru, warspot.ru, файлообмінні портали farposst.ru, mirageswar.com тощо. Саме цими джерелами користуються підлітки в українських школах, студенти та курсанти ВВНЗ при виникненні питань, написанні різноманітних робіт (рефератів) на авіаційну і ракетну тематику. Такий стан речей приводить до дуже поганих наслідків. Прикладом можуть слугувати останні скандальні події пов'язані зі складанням ЗНО з історії [12].

Ще одним важливим моментом, який лакмусовим папірцем показав загальне відношення до історії авіації і ракетної тех- 
ніки, став 100-річний ювілей Повітряних Сил України. Ця дата могла визначатися 2017 року і стати відліком нової сторінки історії української авіації. Але іï проігнорували як музейні установи, науковці, так i керівництво Повітряних Сил. Особливо здивувала байдужість наукової спільноти, тим більше, що історіографія цього питання достатньо опрацьована такими відомими українськими дослідниками як доктори історичних наук Я.Ю. Тинченко, А.І. Харук, кандитат історичних наук В.Р. Мараєв та інші.

Зовсім інший підхід до 100-річча своєї авіації можна було побачити в Європейських державах та Російський Федерації. Остання відзначала свій ювілей ще 2012 року, масштабними заходами державного рівня, причому підготовка до цього святкування розпочалася аж за два роки.

Так само масштабно відзначили свій ювілей і Королівські ВПС Великої Британіiі. На заходах 2018 року була присутня королівська родина. Авіаційні шоу, паради і зібрання історичних спільнот тривали декілька днів. На аеродромі Хендон, в ангарі, під крилом літаючого човна «Сандерленд» був проведений фантастичний святковий обід.

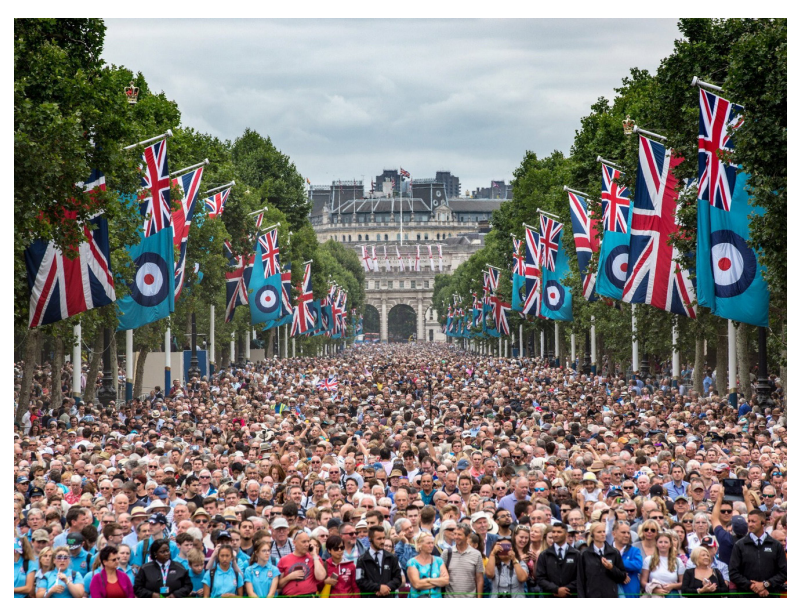

Святкування 100-річча Королівських ВПС Великобританії
2018 рік. 100 років ВПС Польщі відзначено чисельними авіаційними шоу, прийомами та публікаціями у пресі. Навіть мурали на стінах будинків були присвячені цій події.

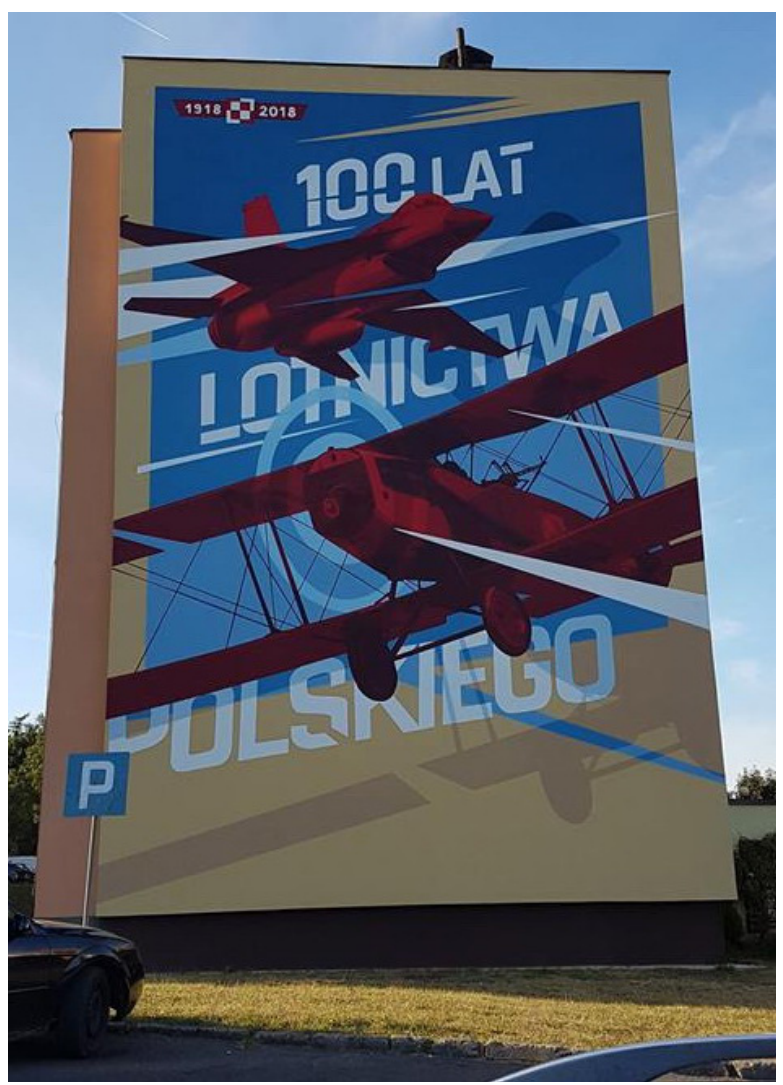

Мурал присвячений 100-річчу ВПС Польщі

Ігнорування аналогічної дати в Україні логічного пояснення не має. Нажаль такі конче потрібні установи, як воєнно-історичний відділ при ГШ ЗС України і сектор воєнно-історичної політики при Департаменті військової освіти, науки, соціальної та гуманітарної політики Міноборони були створені запізно.

Аналізуючи воєнно-історичні заходи, які періодично проходять в Україні, вимальовується системна лінія досить зневажливого відношення до історії української авіації.

Яскравий приклад - остання виставка організована Українським інститутом національної пам'яті «Українське військо 
1917-1921». На думку авторів вона розповідає: «про початки Українського війська та його організацію, легендарних командирів, роди військ ...» [3]. Дійсно, окремі стенди мають назви: «Піхота», «Кіннота», «Артилерія», «Технічні частини», «Флот та морська піхота», «Тили і служби». А де ж «Авіація»? А авіацію шановні автори поставили на стенд «Технічні частини» і виділили для неї клаптик, площею менш половини стенду і два абзаци тексту.

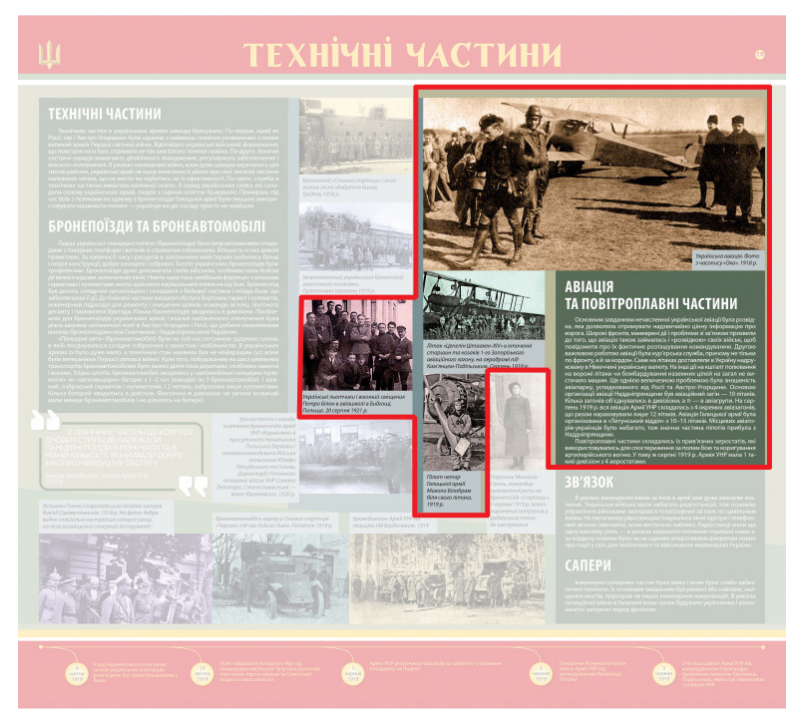

Стенд 3 виставки УІНП.

Відмічено мізерну порцію інформації про українську авіацію

Широко розрекламована книжка «Історія українського війська» [4], яка вийшла друком у 2016 році теж не містить відомостей про історію української авіації, ракетної техніки та засобів ППО. В ній взагалі не розглянута відповідна військова техніка. Прогортаючи книжку, складається враження що українці до цих пір воюють на конях. Якщо подивитися на структуру матеріалу, то мабуть так воно і є, бо на скіфів, сарматів і татар у авторів пішло 180 сторінок, на козацтво і імперський період - 100, майже 60 сторінок зайняла історія Перших визвольних змагань, 10 сторінок витратили на історію Кар- патської України і ще по 10 сторінок!!! автори відвели на Українську повстанську армію і сучасні Збройні сили. Може вони дуже поспішали, і поставили в книгу те що було під рукою, не замислюючись над концепцією такого серйозного та масштабного видання. Невже автори сподівалися, що їі буде цікаво читати майбутнім льотчикам, ракетникам, і я вже не кажу про моряків, зв'язківців та інших військових.

Єдиною музейною установою 3 величезною потенцією в плані історії авіації $\epsilon$ Державний музей авіації України імені О.К. Антонова. Він має гарну колекцію літальних апаратів, авіаційних двигунів тощо. Однак його експозиція містить деякі недоліки. Наприклад, для ілюстрації історії Ту-144 використана картина, на якій в аеропорту Домодедово Головний маршал авіації СРСР Б.П. Бугаєв, особистий пілот Л.І. Брежнева, тисне руку командиру літака Ту-144 Б.Ф. Кузнецову, який здійснив свій політ на честь 60-ї річниці Жовтневої революції. Може цей епізод у когось і викличе ностальгію, однак використовувати такі речі для виховання майбутніх українських авіаторів неприпустимо. Також звертає на себе увагу незадовільний рівень підготовки екскурсоводів, які в своїй розповіді припускаються великої кількості прикрих помилок. На відео, яке викладене в YouTube [11] можна почути байки, в буквальному сенсі, про всеракурсні ракети на МіГ-21, про чудо-РЛС винищувача МіГ-23, про пошук підводних човнів за допомогою магнетрону, абсолютно хибну розповідь про двигун Р-95Ш і багато чого іншого. Все це дуже негативно впливає на імідж музею.

Сам музей розташовано в Києві і його потенціал не може бути використаний у виховному чи навчальному процесі університету. 


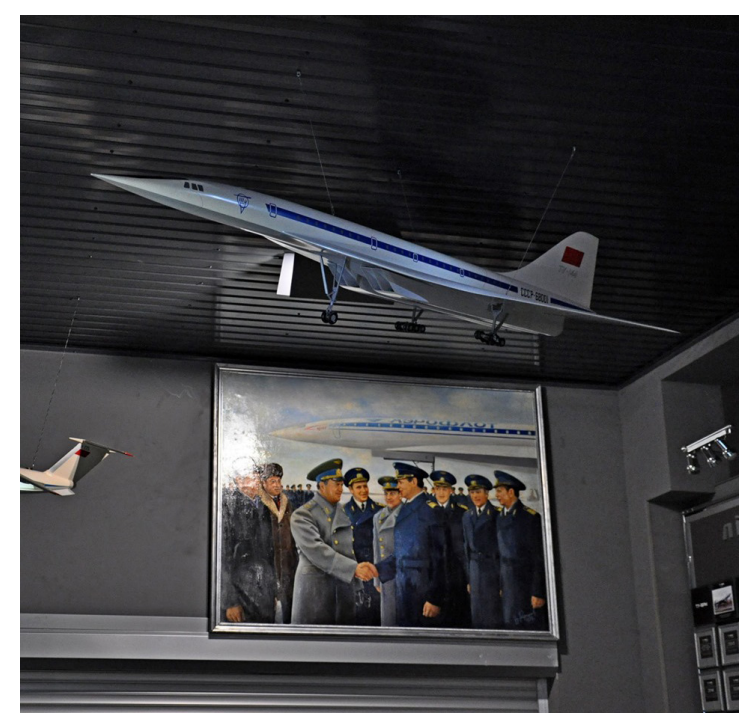

Картина в Державному музеї авіації України, присвячена першому рейсу Ту-144 в Алма-Ату

Всі ці чинники негативно позначалися і позначаються на вихованні майбутніх українських військових авіаторів і опосередковано впливають на моральний стан особового складу, а також на відношення військовослужбовців до розбудови Збройних Сил України в майбутній професійній діяльності.

3 проведеного аналізу витікали мета і завдання майбутньої експозиції, яка би висвітлювала не тільки історію університету, а й показувала історію української авіації, повітроплавання, засобів ППО, радіолокації та зв'язку. Треба було знайти в загальному історичному контексті «українські острівці», зв'язати їх між собою і визначити візуальну форму подачі цієї інформації.

Розроблена концепція визначала новий музей ХНУПС, як профільний воєнно-історичний заклад, який є невід'ємною частиною інформаційно-освітнього простору університету. Музей повинен забезпечити:

- збереження та упорядкування історичної спадщини харківських військових навчальних закладів, які увійшли до його складу;

— патріотичне виховання особового складу;
— популяризацію історії авіації, техніки ППО, радіолокації та зв'язку;

— ведення наукової та видавницької роботи;

- проведення просвітницьких заходів;

- проведення військово-історичних конференцій, засідань історичних спільнот та інших активів музею;

— проведення на базі музею занять 3 особовим складом;

- проведення заходів для цивільної молоді з метою заохочення до вступу в університет.

Експозиція музею зберігала свій комплексний характер і розгорталася в історичному контексті розвитку військової техніки. Університет повинен був отримати воєнно-історичний культурний простір, в якому можна виховати сучасного українського офіцера. В концепцію закладалася ціла низка інноваційних рішень.

\section{Форми реалізації концепції}

Для досягнення цілей і рішення поставлених задач була розроблена тематична структура і новий план експозиції. Вони передбачали створення двох взаємопов'язаних постійних виставок.

Перша виставка — унікальний багатотраєкторний тематико-експозиційний комплекс, який охоплює майже 250 років історії українського повітроплавання, авіації та сил ППО. Він розміщується на 5-му поверсі клубу і складається з 38 стендів та 200 експонатів в сьомі секціях. Представлені зразки, макети ракетного та авіаційного озброєння, льотного спорядження різних часів, рятувальні засоби тощо.

Стенди містять фото, документи та історичні відомості, пов'язані з українською історією. На відміну від традиційного музейного підходу, коли вони демонструються самі по собі, в музеї ХНУПС вони показані 
в загальносвітовому історичному контексті та виділені в ньому.

Для ілюстрації нового підходу можна навести гіпотетичний випадок. Наприклад, якщо в музеї було би потрібно висвітлити історію Ту-144, то поруч 3 його моделлю чи фото слід розташувати мапу світу, на якій накреслити маршрути за якими літали радянський Ту-144 і англо-французький літак «Конкорд». Тоді, навіть неосвічений відвідувач, зможе визначити роль і місце Ту-144 в історії.

Саме такий підхід дозволить побороти штампи радянського минулого і російської пропаганди, відірватися від погляду на українську воєнну історію як на частину «загальнорадянської», дасть змогу провести порівняльний аналіз, наглядно показати місце видатних українців, української авіації та ракетної техніки у світовій історії.

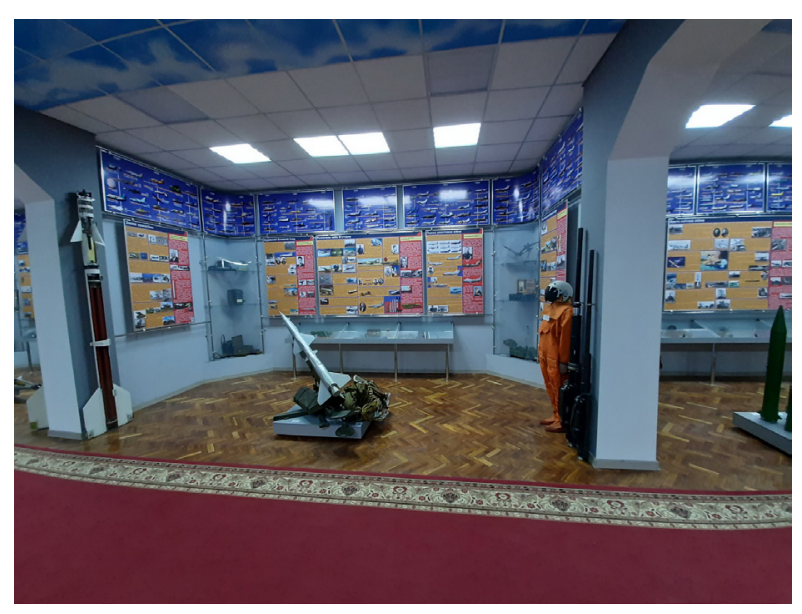

Інтер’єр музею ХНУПС, 2020 рік

В верхній частині експозиції, по всьому периметру приміщення, знаходиться панель у форматі Timeline, яка охоплює період з 1872 по 2020 рік і висвітлює світову історію розвитку повітроплавання, авіації та засобів ППО. Протяжність панелі 70 метрів. Вона містить більше 700 типів літаків і 100 гелікоптерів, майже 40 - ЗРК і 30 літальних апаратів легше повітря.
Розроблена структура експозиції дозволяє мати декілька сценаріїв іiі проходження - траєкторій. Наприклад: «Авіація України в Перших визвольних змаганнях», «Історія повітроплавання в Україні і їі місце в світовій історії», «Українські авіаконструктори», «Історія засобів ППО», «Авіація в локальних війнах» тощо. Фактично, кількість траєкторій і їх тематика не мають меж. Завдяки компоненту Timeline будь яке питання $з$ історії техніки може бути грунтовно вирішено прямо на місці.

При розробці дизайну експозиції прискіплива увага приділялася брендуванню музею, що в майбутньому дозволить створити яскравий образ установи в сучасному інформаційному просторі. На вході облаштована сучасна фотозона з логотипами музею та університету.

Друга виставка розміщена на шостому поверсі, вона складається з двох розділів. Перший - висвітлює історію університету i його досягнення, а другий - присвячено подіям російсько-української війни та участі в ній особового складу університету. Ця виставка знаходиться на етапі розбудови.

Реалізація концепту почалася в травні 2019 року. Робота проводилася за підтримки начальника університету генерал-майоpa О.В. Туринського, заступника начальника університету з морально-психологічного забезпечення полковника В.В. Лук'яненко. Розбудову здійснювали: начальник клубу університету О.О. Попов, художник В.В. Старіков, завідувач музею О.Г. Шаповал, офіцер відділу з морально-психологічного забезпечення старший лейтенант А.С. Курячий. Активну участь в роботі брали курсанти - члени науково-історичного гуртка. Допомогу з поповненням фондів зразками озброєння музею надавали начальники кафедр. Кропітку роботу по створенню моделей авіатехніки виконав службовець ЗС України М.М. Околелов. 
Дизайн, інформаційну та наукову підтримку забезпечував розробник концепції службовець ЗС України О.А. Чечин.

В даний час перша виставка повністю закінчена і вже вирішує окреслене в концепції коло задач.

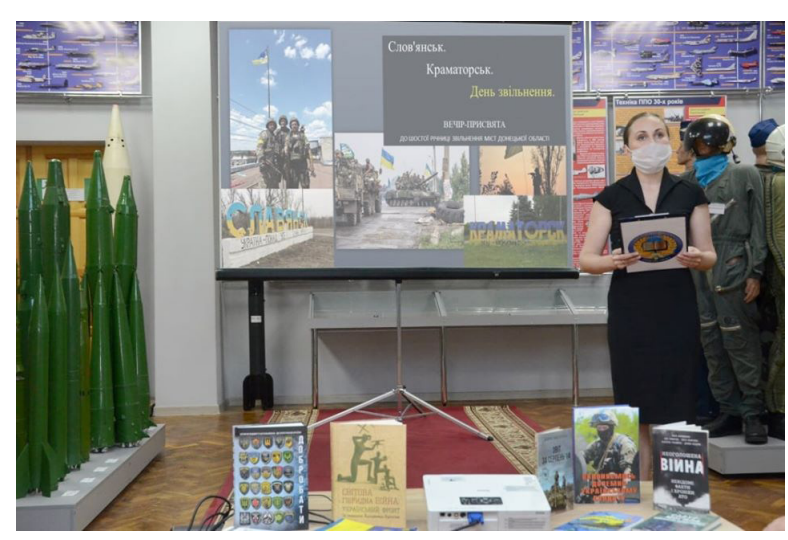

Проведення заходів присвячених річниці звільнення українських міст від російських загарбників

\section{Інноваційні рішення в музеї}

Як правило, відвідувачі взаємодіють з експозицією через кваліфікованого спеціаліста - екскурсовода, який є своєрідним посередником між ними та експонатами. До недавнього часу екскурсія була основою роботи музею, але з розповсюдженням інформаційних технологій ситуація докорінно змінилася. 3'явилися нові форми взаємодії, які розширюють інформаційний простір, дозволяють добитися ефекту занурення відвідувачів у історичний контекст, додають в експозицію інтерактивність, елементи гри та інше.

Люди в сучасному музеї вже не $\epsilon$ пасивними глядачами або слухачами заздалегідь завченого тексту, тепер вони стають активними учасниками процесу відвідання. Завдяки використанню індивідуальних цифрових пристроїв відвідувачі можуть самостійно обирати: форму інформації, ступінь деталізації, кількість та темп її подачі.
Також, нові технології дозволяють істотно розширити аудиторію і віртуалізувати роботу музею. Зрозуміло, що сучасний музей не може бути актуальним і конкурентним без залучення таких інновацій.

При розробці нової концепції передбачалося використання таких елементів як: мультимедійність, інтерактивність, доповнена реальність, QR-коди, NFC-мітки. Було розроблене програмне забезпечення системи інформаційної підтримки музею.

Мультимедійність. В експозицію додавався аудіовізуальний контент, пов'язаний 3 кожною окремою секцією експозиції. Наприклад, фонові звукові ефекти для занурення в історичний контекст. В секції Перших визвольних змагань чути кулеметні черги, звуки поршневих моторів, а в секції локальних війн другої половини ХХ-го століття - звук реактивних двигунів. Особисті цифрові пристрої відвідувачів дозволяють отримати доступ до додаткових джерел інформації, побачити експонати 3 інших ракурсів, познайомитися 3 їх деталями. В перспективі планується використання 3D-фото та фото у форматі «360».

Відпрацьований мультимедійній контент сприяє розповсюдженню інформації через соціальні мережі та популяризує музей. Музейні матеріали у цифровому вигляді можуть лягти в основу навчальних програм університету або стати частиною виїзної експозиції.

Інтерактивність, яка передбачає реакцію окремих експонатів (стендів) на рух або дотик. Наприклад, при наближенні до стенду включається світло, звук, запускається відтворення відео, починається рух або включаються рухомі макети 3 дистанційним керуванням. Цікавою можливістю $€$ надання відвідувачам індивідуального пристрою активації інтерактивних властивостей, своєрідної «чарівної палички», за допомогою якої він зможе взаємодіяти 
з експонатами, навіть якщо вони сховані за склом вітрини.

Доповнена реальність (англ. Augmented Reality, далі просто AR) - технологія для яка додає до інформаційного полю музею цифрові дані (фото, відео, 3D-моделі). Для демонстрації цих даних використовуються індивідуальні цифрові пристрої - телефони, планшети тощо. 3 прикладом використання AR можна познайомитися в Музеї українського живопису в місті Дніпро [5]. Перші приклади використання систем AR при вивченні історії були розроблені ще у 2006 році у Массачусетському технологічному інституті, де створили програму Reliving the Revolution (англ. Відродження революції) [6]. Вона дозволяла на місцевості, в усіх подробицях, дослідити історичну битву біля Лексінгтона. Великої популярності набули додатки AR для інтерактивної ілюстрації дитячих книжок.

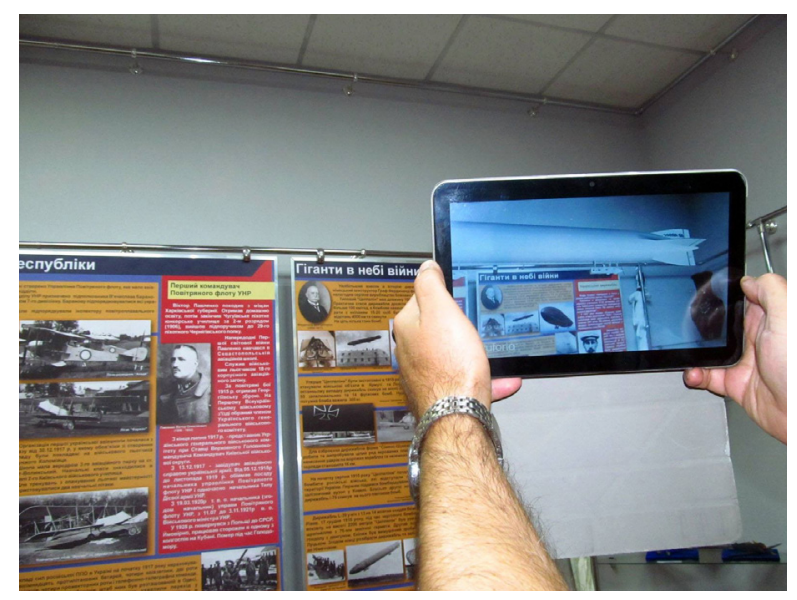

Додаток AR в роботі.

Над стендом з'явився віртуальний об'єкт дирижабль Цеппеліна

Для музею ХНУПС розроблено пілотний додаток для ОC Android, який демонструє 3D моделі при наведенні на інформаційні стенди камери смартфону, причому встановлювати спеціальну мітку на стенд не потрібно.

$Q R$-коди теж не є принципово новою музейною технологією для України. Пер- ші QR-коди були використані 2010-го року у Львові та 2013-го — в Музеї історії Києва [7; 8]. В більшості випадків за допомогою QR-коду в музеях влаштовують посилання на аудіогід Izi.Travel, яке містить фото, невеличкий текст та хвилинний аудиозапис.

Для проведення екскурсій з закордонними відвідувачами часто використовують WEB-систему QRpedia [9], яка зв'язує експонати зі статями Вікіпедії на мові господаря мобільного пристрою. QRpedia широко використовується в музеях таких країн, як Австралія, Болгарія, Чехія, Естонія, Німеччина, Іспанія, Великобританія i США.

Як i в наведених прикладах QR-коди в музеї ХНУПС розширяють інформаційну базу, деталізують елементи експозиції, а також надають доступ до аудиовізуального контенту.

Більш сучасним аналогом QR-кодів є NFC-мітки. Нажаль ще не у всіх відвідувачів є мобільні пристрої, які мають необхідні технічні можливості, тому NFC-технологія в музеї ХНУПС використовуються як допоміжна, зокрема, для авторизації при вході у локальну бездротову мережу.

Система управління контентом. При проектуванні цифрової складової експозиції було прийнято рішення розгорнути в музеї локальну бездротову мережу. По-перше, вона надає безкоштовний доступ до інформаційних ресурсів. По-друге - дає можливість розробити і запустити в дію своє програмне забезпечення. Ще однією перевагою такого рішення є те, що інформаційна база, яка використовується на локальному WEB-сервері, недоступна з боку мережі Internet, в той самий час як ресурси Internet доступні на пристроях клієнтів. Це дозволяє використовувати в цифровій експозиції унікальний контент, який не можна переглянути зовні. 
Розроблене серверне програмне забезпечення фактично є системою інформаційної підтримки музею. Воно включає сховище мультимедійних матеріалів і систему управління контентом.

Повний контроль над сервером дозволяє збирати цінні статистичні дані. Наприклад, яка саме інформація користується найбільшою популярністю, оперативна кількість відвідувачів в мережі, частоту використання QR-кодів, міток тощо.

Система управління контентом дозволила докорінно змінити принцип роботи 3 QR-кодами в інформаційному просторі музею. На відміну від стандартного підходу, в якому один код назавжди зв'язаний 3 конкретною WEB-сторінкою, інформаційні зв'язки QR-кодів в музеї ХНУПС динамічні - 3 однією наліпкою чи стікером може бути пов'язана необмежена кількість сторінок. Встановлення необхідних зв'язків виконуються через WEB-інтерфейс безпосередньо перед початком роботи, або в процесі екскурсії. Такий інноваційний підхід дозволяє:

- мати фіксовану кількість міток;

- оперативно міняти контент мітки при проведенні екскурсій на різні тематики;

- задовольняти потреби людей з обмеженими можливостями;
— влаштовувати інтелектуальні змагання, наприклад, у формі «музейного квесту».

B останньому випадку QR-кодами можна зашифрувати завдання, питання, вказівки до маршрутів, і взагалі відмовитися від паперових носіїв (конвертів) при проведенні гри. Причому в будь-який момент можна повернутися к «екскурсійному» використанню тих самих міток.

\section{Перспективи розвитку музею}

В перспективі планується закінчити розбудову другої виставки, збільшити кількість зразків та макетів зброї. Налагодити співробітництво з іншими музеями. За допомогою сучасних інформаційних технологій побудувати перехресні інформаційні зв'язки між експонатами різних музеїв, доповнюючи інформаційне поле одного музею інформацією з іншого. Відправною точкою для такого зв'язку може бути NFC-мітка чи QR-код. Інформаційний масив кожного музею буде зберігатися на особистому сервері інформаційної підтримки. Таким чином, в Україні можна побудувати єдиний інформаційний військово-історичний простір.

\section{ДЖЕРЕЛА ТА ЛІТЕРАТУРА}

1. URL: http://museums.kh.ua/-muzobereg — [Посилання дійсне на 20.06.2020].

2. Пашкова О.О. Вітчизняна воєнно-історична періодика у військово-патріотичному вихованні курсантів ВВНЗ// Воєнно-історичний вісник, 2019, вип. 2(32). - С.19-36.

3. URL: https://uinp.gov.ua/vystavkovi-proekty/vystavka-ukrayinske-viysko-1917-1921[Посилання дійсне на 20.06.2020].

4. Історія українського війська / Кирило Галушко та ін.; за ред. В. Павлова. Харків, 2006. $405 \mathrm{c}$.

5. URL: http://museum.net.ua/afisha/dopovnenu-realnist-prezentuvali-u-muzeï-ukraïnskogozhivopisu/ — [Посилання дійсне на 20.06.2020]. 
6. URL: http://www.gamecareerguide.com/features/263/student_postmortem_reliving_the_. php — [Посилання дійсне на 20.06.2020].

7. URL: http://vikz.org.ua/qr-koduvannya-storiko-kulturnih-pam-yatok-vishgorodschini-1topis-pro-ktu.html — [Посилання дійсне на 20.06.2020].

8. Бєлікова М.В. Запровадження інноваційних технологій в музеях України // Наукові праці історичного факультету Запорізького національного університету, 2015, вип. 43. C. $326-330$.

9. URL: http://uk.wikipedia.org/wiki/QRpedia — [Посилання дійсне на 20.06.2020].

10. URL: https://www.peytonandbyrne.co.uk/sites/default/files/2019-12/RAF\%20Museum\% 20Evening.pdf — [Посилання дійсне на 20.06.2020].

11. URL: https://www.pravda.com.ua/articles/2020/07/10/7258820/ — [Посилання дійсне на 12.07.2020].

12. URL: https://www.pravda.com.ua/news/2020/07/11/7258992/ — [Посилання дійсне на 12.07.2020].

Chechin O.A., lecturer at the Military College

of Sergeants of the Ivan Kozhedub National

Air Force University of Ukraine

(Kharkiv, Ukraine)

\section{HISTORY OF KHNUPS MUSEUM, CONCEPT AND INNOVATION}

The article considers the history of the museum of Kharkiv National University of the Air Force named after Ivan Kozhedub. The concept of the museum and forms of its realization are shown. Special attention is paid to innovative solutions and the use of modern information technologies in museum business. Prospects for the development of the museum are outlined. A model of a single information space for military museums is proposed.

Key words: history, museum, analysis, concept, innovation, multimedia, interactivity, QR-code, content, system. 